\title{
The effect of road traffic on a breeding community of woodland birds
}

\author{
Marcin Polak • Jarosław Wiącek • Marek Kucharczyk • \\ Robert Orzechowski
}

Received: 24 October 2012/Revised: 1 July 2013/Accepted: 9 August 2013/Published online: 21 August 2013

(C) The Author(s) 2013. This article is published with open access at Springerlink.com

\begin{abstract}
The very rapid development of the road infrastructure in recent years has adversely affected the natural environment. The main effects of this have been the loss or deteriorating quality of habitats, the mortality of animals due to collisions with road vehicles, the withdrawal of birds as a result of disturbance and excessive noise in the neighbourhood of roads. In this study, we attempted to define the influence of a busy road on a breeding community of woodland birds. Individuals were counted using the point method at 54 observation points located at three various distances $(60,310,560 \mathrm{~m})$ from the road. At each point, we determined the habitat parameters and the intensity of noise. In total, 995 individuals of 39 species were recorded on the study plot. This study showed that the area was homogeneous with respect to habitat. The number of birds per point increased with distance from the road. Species diversity was lower near the road. The density of nine common species increased with distance from the road. Great Tit Parus major and Song Thrush Turdus philomelos preferred the neighbourhood of the road, whereas the numbers of the other species were the highest in the middle row of points. The number and species diversity of birds were correlated with the pattern of sound propagation across our study area. Our results showed that
\end{abstract}

Communicated by J. Müller.

M. Polak $(\bowtie) \cdot$ J. Wiącek $\cdot$ M. Kucharczyk

Department of Nature Conservation, Institute of Biology and

Biochemistry, Maria Curie-Skłodowska University, Akademicka 19, 20-033 Lublin, Poland

e-mail: mpolak@hektor.umcs.lublin.pl

R. Orzechowski

EKO-KLIMAT, Ostrobramska 101/243, 04-041 Warsaw, Poland the species particularly sensitive to road traffic were those nesting near the ground and with low-frequency calls.

Keywords Biodiversity - Traffic noise $\cdot$ Forest management $\cdot$ Disturbances

\section{Introduction}

The dynamic development of road infrastructure and the colossal rise in the number of vehicles using the roads are going to pose an increasing threat to the proper functioning of many animal populations around the world (Fahrig et al. 1995; McGregor et al. 2008). The adverse effects of road traffic on animals have been described quite extensively in the literature (Spellerberg and Morrison 1998; Forman and Sperling 2003; Fahrig and Rytwinski 2009). Particularly, numerous are papers on the negative influence of the construction and operation of new roads on birds, which are model organisms for this type of study (Reijnen et al. 1997; Kuitunen et al. 2003; Pescador and Peris 2007). Most studies indicate that roads carrying heavy traffic have led to a reduction in density and species richness of birds nesting in the immediate vicinity (Reijnen et al. 1995; Reijnen et al. 1996; Palomino and Carrascal 2007) although some authors have found that species behave neutrally or even prefer the neighbourhood of transport routes (Clark and Karr 1979; Adams and Geis 1981; Benitez-López et al. 2010). Researchers have specified the following significant threats resulting from the expansion of road infrastructure: impoverishment and fragmentation of habitats (Ortega and Capen 1999; Šálek et al. 2010), mortality resulting from collisions with vehicles (Orłowski 2005, 2008), the withdrawal of birds as a result of their being disturbed by excessive traffic noise (Wiley and Richards 1982; Wood 
and Yezerinac 2006; Slabbekoorn and Ripmeester 2007; Lackey et al. 2011), optical disturbance resulting from people penetrating roadside verges and vehicle lights (Pocock and Lawrence 2005), and the excessive emission of vehicle pollutants, which can accumulate in the bodies of birds or impoverish their food resources (Summers et al. 2011). Difficulties in vocal communication caused by traffic noise appear to be one of the main problems affecting the functioning of birds in a noise-polluted environment (Brumm and Slabbekoorn 2005). Traffic noise can modify behaviour and certain parameters of bird populations, namely, it can reduce breeding success (Kuitunen et al. 2003; Halfwerk et al. 2011), hamper the search for a suitable partner (Brumm 2004; Habib et al. 2007) and compel changes in the loudness and frequency of songs during the courting period (Salaberria and Gil 2010). Moreover, it can have an impact on parent-offspring vocal communication, and adults may therefore not be able to meet their nestlings' demands (Leonard and Horn 2008). Traffic noise can also elicit changes in physiological processes of birds, functioning under stressful conditions, and these in turn may induce changes in their behaviour at various stages of their life cycle (Dooling and Popper 2007).

Recent studies have indicated that some bird species manage to live in a noise-polluted environment quite well, protecting themselves from its negative effects by using adaptations like the Lombard effect, i.e. increasing the amplitude of song (Brumm 2004), changing the frequency spectrum to a higher one (Salaberria and Gil 2010; Bermudez-Cuamatzin et al. 2012), singing at a time of day when noise levels are lower (Fuller et al. 2007) and intensifying the level of vocalization (Brumm and Slater 2006; Diaz et al. 2011). Despite a wealth of research in recent years, we still have too few empirical data from which to derive a mechanism explaining the various interactions between road traffic and birds (Summers et al. 2011). In such studies, the influence of variable environmental parameters that could blur the final picture needs to be controlled (Fahrig and Rytwinski 2009). Noise is most probably one of the main factors acting on bird populations inhabiting the vicinities of roads, but the basic problem is the synergistic effect of different habitat factors and anthropogenic parameters that shape and modify such populations (Dooling and Popper 2007).

The basic objective of our research was to examine whether the neighbourhood of a busy road affected the numbers and species richness of woodland birds. We controlled the potentially modifying influence of the structure and variability of the habitat on the density of birds breeding in our study plot. The available data indicate that roads do reduce the density and species richness of birds nesting in their vicinity (Reijnen et al. 1996;
Palomino and Carrascal 2007). But this does not apply to all species, and little is known of the impact of roads on particular species/guilds, so we were interested to find out which ones sustained the greatest losses and which remained unaffected by the road. In order to perform a precise analysis, we distinguished habitat-feeding and bioacoustics guilds. Since road noise masks the vocal communication of birds primarily in the low-frequency region (Dooling and Popper 2007) and because of the optical disturbance of birds by humans and passing vehicles (Pocock and Lawrence 2005), we assumed that the species most likely to be adversely affected by road noise would be those producing low-frequency sounds/calls and those nesting on the ground. In order to assess the significance of the effect of noise on birds, one of the aims of this work was to model the propagation of noise across our research plot. We set up the hypothesis that the numbers of birds and their species richness falls in accordance with the model of noise propagation over the study area (the traffic noise hypothesis; Summers et al. 2011). If this is the case, then noise is indeed the main factor responsible for the adverse effects on birds. The estimation of road effect and establishment of which factors affect species richness/ abundance of birds is an essential issue as regards the protection of individuals living in habitats in the vicinity of roads (Halfwerk et al. 2011). These data are sorely required if we intend to propose an effective conservation strategies and management plans for woodlands adjacent to the roads.

\section{Methods}

The field work was carried out in the Janów Forest in south-eastern Poland (N50 $41^{\prime}-27^{\prime}$ E22 $2^{\circ} 17^{\prime}$; Fig. 1). This extensive and closed-canopy forest complex lies on flat terrain, but there are dune hillocks in places. The habitats are mostly coniferous woodland, but alder woods grow in the depressions and river valleys. The principal tree species is the Scots pine Pinus sylvestris and to a lesser extent, silver birch Betula pendula, oaks Quercus sp., spruce Picea abies and fir Abies alba. The study was done along the twolane national road No. 19 between Janów Lubelski and Łążek Ordynacki (Fig. 2). According to data from a 2005 study by the General Administration for National Roads and Motorways, traffic intensity in the Janów Forest was 8,738 vehicles per $24 \mathrm{~h}$, including 6,842 cars and minibuses, 1,739 lorries, 131 buses/coaches and 26 motorcycles. In 2010, the traffic intensity was 6,673 motor vehicles per $24 \mathrm{~h}$. There is a speed limit of $90 \mathrm{~km} / \mathrm{h}$ along this stretch. In our study area, it was equally hung about 150 nest-boxes (Fig. 2). The distribution of nest-boxes was independent from the distance from road. 


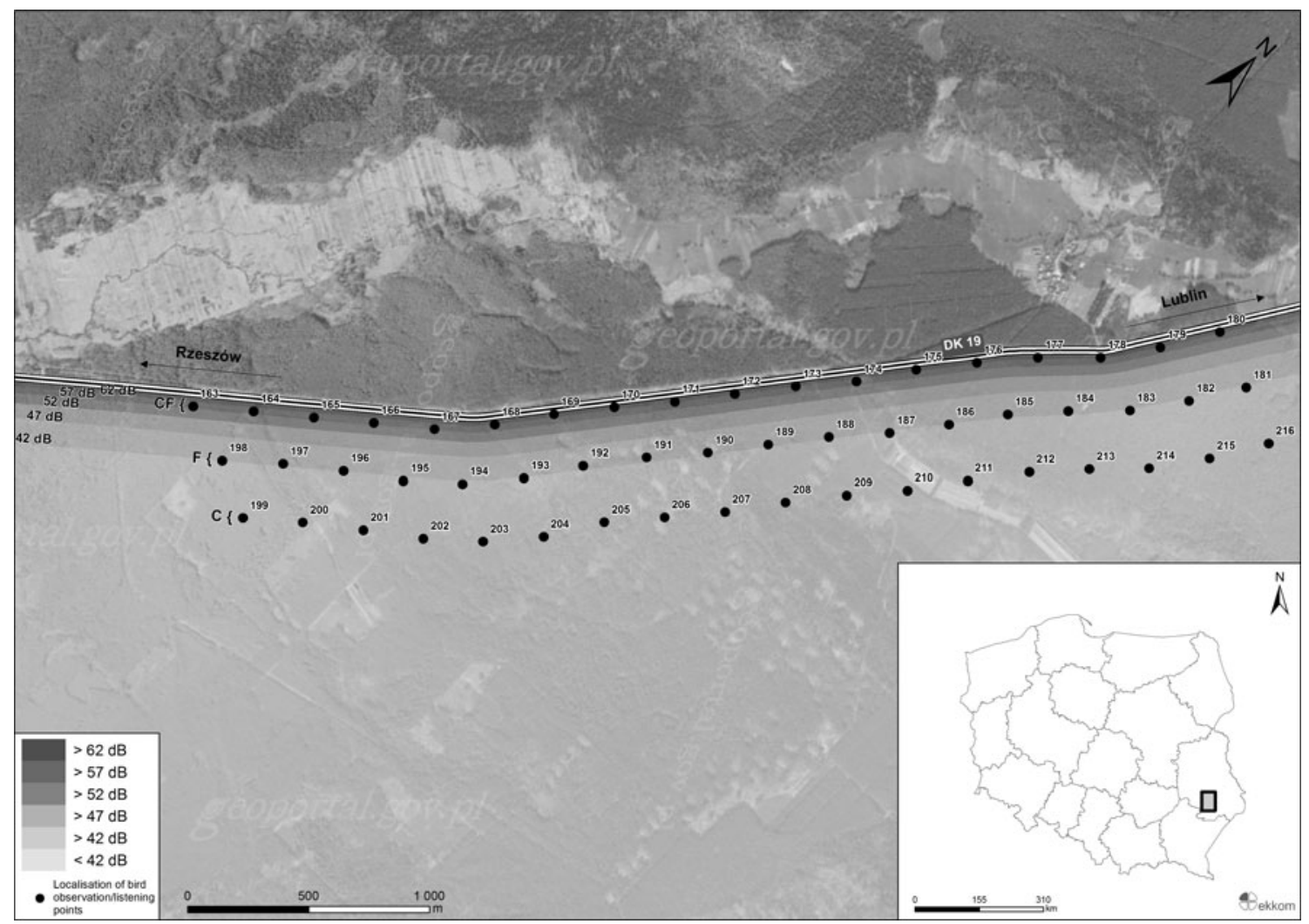

Fig. 1 The study plot with the point-count locations (black dots) and noise-level isolines near road in Janów Forest (eastern Poland)

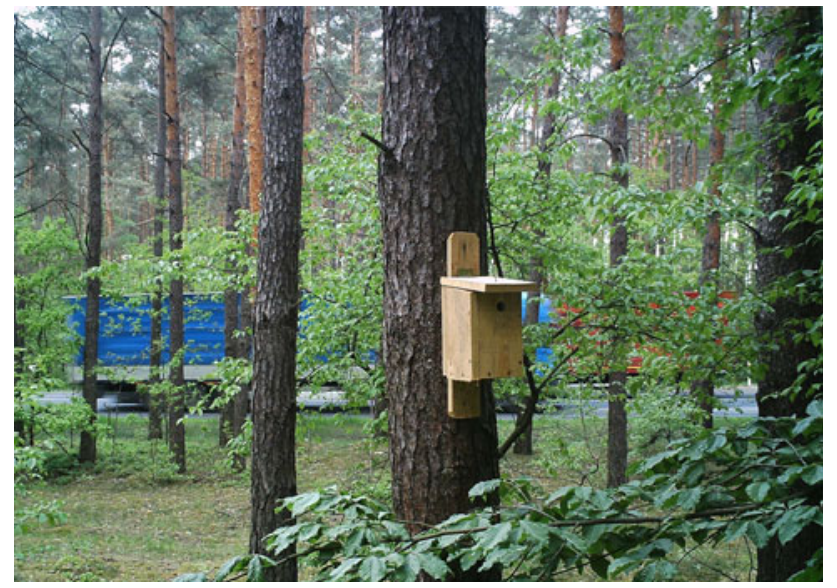

Fig. 2 The study area was done along the two-lane national road No. 19 between Janów Lubelski and Łążek Ordynacki (eastern Poland)

The clustering of woodland birds was determined using the point-count method (Bibby et al. 1992). The study was done at 54 observation/listening points located along three lines running parallel to the road (Fig. 1). All the points were established and recorded in GPS receivers in March 2011 before the start of the actual counting. The first row of 18 points (further called CF-points) lay $60 \mathrm{~m}$ from the road, the next row of 18 points (F-points) was situated
$310 \mathrm{~m}$ from the road, and the last row of 18 points $(\mathrm{C}-$ points) ran at a distance of $560 \mathrm{~m}$ from the road. All the points were $250 \mathrm{~m}$ apart from one another. Counting at each point lasted for $5 \mathrm{~min}$. All the birds seen and heard within a radius of $100 \mathrm{~m}$ were recorded, but birds flying over the study plot were not counted. Three counts were done at each point—on 20 April 2011, 19 May 2011 and 9 June 2011. All the counts were done in the morning hours from dawn to 10:00 $\mathrm{h}$. In order to limit the time-of-day effect, counting on each day was done in a different order, and the next count was started at the point where the previous one had finished. The counting route was S-shaped, and the observation points were visited in the following order: CF, F, C, C, F, CF, CF and so on. The counts at all the points on one morning were performed by two experienced observers (MP and JW). To minimize the observer effect, the points monitored by one of the observers were monitored by the other during the next counting session. Before the counts were started, the study plot was selected very carefully in order to reduce to an absolute minimum, the effect of environmental parameters on bird clustering. To minimize the edge effect, the plot was located in the depths of a large, dense forest complex (Fig. 1). The structure of the vegetation at every listening point was assessed with the aid of eleven environmental parameters (see Table 1). 
Table 1 The habitat variables obtained at the point-count locations

\begin{tabular}{|c|c|}
\hline Variable & Meaning \\
\hline Tree age (years) & Age of tree stand at the point-count location (years) \\
\hline Canopy cover $(\%)$ & $\begin{array}{l}\text { \% canopy cover in eleven categories: } 0-0 \% ; 10-1-10 \% ; 20-11-20 \% ; 30-21-30 \% ; 40-31-40 \% ; 50-51-60 \% \text {, } \\
\quad 60-61-70 \%, 70-71-80 \%, 80-81-90 \%, 90-91-99 \%, 100-100 \% \text { within circle (radius } 30 \mathrm{~m} \text { ) }\end{array}$ \\
\hline Tree height (m) & Mean height of 5 trees growing within circle (radius $30 \mathrm{~m}$ ) and measured by the altimeter \\
\hline $\begin{array}{l}\text { Number of tree } \\
\text { species }\end{array}$ & Number of species of the nearest 30 trees that were $>20 \mathrm{~cm}$ diameter at breast height \\
\hline $\begin{array}{l}\text { Number of deciduous } \\
\text { trees }\end{array}$ & Number of deciduous trees of the nearest 30 trees that were $>20 \mathrm{~cm}$ diameter at breast height \\
\hline Number of dead trees & Number of dead trees that were $>20 \mathrm{~cm}$ diameter at breast height within circle (radius $50 \mathrm{~m}$ ) \\
\hline DBH $(\mathrm{cm})$ & Diameter at breast height \\
\hline $\begin{array}{l}\text { Number of shrub } \\
\text { species }\end{array}$ & Number of shrub species and/or young trees $(<20 \mathrm{~cm}$ diameter at breast height) growing within circle (radius $30 \mathrm{~m})$ \\
\hline Shrub cover $(\%)$ & $\begin{array}{l}\text { \% shrub cover in eleven categories: } 0-0 \% ; 10-1-10 \% ; 20-11-20 \% ; 30-21-30 \% ; 40-31-40 \% ; 50-51-60 \% \text {, } \\
\quad 60-61-70 \%, 70-71-80 \%, 80-81-90 \%, 90-91-99 \%, 100-100 \% \text { within circle (radius } 30 \mathrm{~m} \text { ) }\end{array}$ \\
\hline Herb cover $(\%)$ & $\begin{array}{l}\% \text { herb cover in eleven categories: } 0-0 \% ; 10-1-10 \% ; 20-11-20 \% ; 30-21-30 \% ; 40-31-40 \% ; 50-51-60 \%, 60-61- \\
70 \%, 70-71-80 \%, 80-81-90 \%, 90-91-99 \%, 100-100 \% \text { within circle (radius } 30 \mathrm{~m} \text { ) }\end{array}$ \\
\hline Herb height $(\mathrm{cm})$ & Mean height of herb vegetation at 5 places chosen randomly within circle (radius $30 \mathrm{~m}$ ) \\
\hline
\end{tabular}

Three different approaches were applied to determine the model of the propagation of noise across our study area: (1) direct measurement sound levels at counts, (2) acoustic map and (3) the calculations yielded the equivalent noise level A-LAeq. The level of road noise was measured at all the points during every count in April, May and June using a digital sound-level metre CHY 650 (IEC 651-1979 Type 2, ANSI S1.4-1983 Type 2, JIS C 1502). During each measurement, the frequency-weighting setting was set to A, and the time-weighting setting was set to SLOW. The noise level at the centre of each point was measured for $5 \mathrm{~min}$, and the highest level recorded. Traffic noise was measured on weekdays in comparable and stable weather (no rain or high winds). In addition, the propagation of traffic noise in the study area was modelled to produce an acoustic map (Fig. 1). For this purpose, acoustic measurements were carried out in July 2011 between 10-18 h and $22-23 \mathrm{~h}$. The acoustic modelling was done using the following measurement instruments: a sound-level metre (Type 2250), a microphone (Type 4950) and an acoustic calibrator (Type 4231); all the devices were manufactured by Brüel and Kjaer. Measurements were made at six points, two each at each distance class from the road, from which the noise level at each observation point was calculated. The field studies were done using the sampling method, carrying out three 5-min measurements at each point, which were then averaged logarithmically. The measurements were made in good weather without rainfall or wind speeds in excess of $3.0 \mathrm{~m} / \mathrm{s}$. The range of noise measurements involved defining the equivalent noise level $\mathrm{A}\left(\mathrm{L}_{\mathrm{Aeq}}\right.$ in $\mathrm{dB})$, the maximum sound pressure level $\mathrm{A}\left(\mathrm{L}_{\mathrm{Amax}}\right.$ in $\left.\mathrm{dB}\right)$ and the minimum sound pressure level $A\left(L_{A m i n}\right.$ in $\left.d B\right)$.
For calculating the noise of road traffic, we used the French national method of calculation "NMPB-Routes - 96 (SETRA-CERTU-LCPC-CSTB)", set out in "Arrêté du 5 mai 1995 relatif au bruit des infrastructures routières, Journal Officiel du 10 mai 1995, art. 6" and the French standard "XPS 31-133". With regard to input data regarding emissions, these documents refer one to "Guide du bruit des transports terrestres, fascicule prévision des niveaux sonores, CETUR 1980". However, this method of calculation takes no account of propagated sound being absorbed by vegetation. In view of this, sound propagation was calculated according to the Polish standard PN-ISO 9613-2:2002 Acoustics. "Attenuation of sound during propagation in an open space-a general method of calculation". This method takes only two types of vehicle into account: (1) light vehicles weighing $<3.5$ tons, (2) heavy vehicles with a weight of more than 3.5 tons. For the model calculations, we used the IMMI program, version 6.3.1 (Wölfel GmbH and Co). Noise emissions were calculated for a standardized reference time interval: (1) during the day, i.e. from 06:00 to $22: 00 \mathrm{~h}(16 \mathrm{~h}),(2)$ at night, i.e. from 22:00 to 06:00 h $(8 \mathrm{~h})$. The calculations yielded the equivalent noise level A expressed as the so-called short-term index: (1) LAeqD_-daytime and (2) LAeqN_night-time.

The division into feeding, nesting and bioacoustic guilds was done on the basis of publications by Cramp and Perrins (1977-1994). In the present analyses, parametric tests were applied after checking whether the distribution was consistent with the normal distribution (Kolmogorov-Smirnov test; $P>0.05$ ). A bilateral critical region was assumed in the tests, and results were deemed significant if the probability of committing an error of the first kind was $\leq 0.05$. 
Analysis of variance (ANOVA) was used to assess the propagation of noise over the study area and to determine the differences in species richness and numbers in specified categories of observation points. The measure of species richness was taken to be the sum of all species come across during the three counts, and the number of birds was the sum total of all individuals discovered during all three counts. Therefore, multivariate analysis of variance (MANOVA) was conducted to test for variation in avian ecological groups at points located in different distance from road. Redundancy analysis (RDA) was used to analyse the relationship between the numbers of particular bird species and distance from the road - this parameter was used as the environmental variable. Every observation/listening point was placed in one of three classes of distance from the road: points $\mathrm{CF}(60 \mathrm{~m}), \mathrm{F}(310 \mathrm{~m})$ and $\mathrm{C}(560 \mathrm{~m})$. The Monte Carlo test with 500 permutations was used to determine the significance of canonical axes. The means are given together with their standard deviations \pm SD. The computations were performed using the STATISTICA 6.0 program (Statsoft Inc 2001) and the Canoco 4.0 program (ter Braak and Smilauer 1998).

\section{Results}

Meticulous analysis of the environmental parameters showed that the area on which the birds were counted was homogeneous with respect to habitat (Table 2). Only two of the eleven habitat parameters differentiated the study area: the number of dead trees increased and the shrub layer density decreased with distance from the road. During the three counts, a total of 995 individual birds from 39 species (Table 3) were observed. The most numerous species was the chaffinch Fringilla coelebs, which made up $28 \%$ of the birds counted in the study area. The dominants $(\geq 5 \%)$ included a further 6 species: the robin Erithacus rubecula, the great tit Parus major, the coal tit Periparus ater, the blackcap Sylvia atricapilla, the chiffchaff Phylloscopus collybita and the tree pipit Anthus trivialis. The number of the most common birds ( $>10$ inds.) differed widely in relation to distance from the road (Fig. 3; Monte Carlo test of the significance of the first axis; $F$ ratio $=4.232 ; P=0.002$; Monte Carlo test of the significance of all axes; $F$ ratio $=2.40 ; P=0.006)$. The density of the following species increased with distance from the road: the chaffinch, the robin, the coal tit, the chiffchaff, the tree pipit, the blackbird Turdus merula, the cuckoo Cuculus canorus and the jay Garrulus glandarius. The great tit and the song thrush Turdus philomelos preferred the neighbourhood of the road, whereas the numbers of the other common species were the highest in the middle row of points. Species diversity was lower near the road
(ANOVA; $F_{2,51}=14.57 ; P<0.0001 ;$ Fig. 4 ). The mean number of species at CF-points lying closest to the road was $7.3 \pm 1.8$ species $(n=18)$ and differed significantly from the number at F-points $(10.4 \pm 2.5 ; n=18)$ and C-points $(11.2 \pm 2.5 ; n=18)$. The number of individual birds per point increased with distance from the road (ANOVA; $F_{2,51}=21.28 ; P<0.00001$; Fig. 5). The mean number of birds at CF-points was $13.7 \pm 3.1$ (range 10-22; $n=18)$ and was significantly different from the numbers at F-points $(19.3 \pm 4.6 ; 13-30 ; n=18)$ and C-points $(22.3 \pm 4.1 ; 14-28 ; n=18)$. We thus used a MANOVA to test for effects of road on the proportion of individuals in different ecological groups. There was an increase with distance from the road in the number of ground-nesting species (MANOVA; $F_{4,153}=7.29 ; P<0.0005$; Fig. 6) foraging on invertebrates $\left(F_{4,153}=7.30 ; P<0.0005\right)$ and using low-frequency calls for communication $\left(F_{4,153}=\right.$ 4.90; $P<0.001)$.

Three different acoustic methods show the similar pattern, and the noise level declined with distance from the road in all three categories of points. The mean noise intensity during the counts at CF-points was $69.9 \pm 5.0 \mathrm{~dB}$ (range 56.9-81.4 dB; $n=54$ ), at F-points $53.3 \pm 6.0 \mathrm{~dB}$ $(41.0-70.7 \mathrm{~dB} ; n=54)$ and at C-points $50.1 \pm 9.2 \mathrm{~dB}$ (31.2-68.4; $n=54)$. Significant differences were demonstrated in noise propagation between the point categories during the counts in April (Fig. 7; ANOVA; $F_{2,51}=26.82$; $P<0.0001$ ), May (ANOVA; $F_{2,51}=63.57 ; P<0.0001$ ) and June (ANOVA; $\left.F_{2,51}=110.60 ; P<0.0001\right)$. Figure 1 shows acoustic map and a model of the propagation of noise across our study area. The isolines lie parallel to the road: the first row of points coincided with the $60 \mathrm{~dB}$ isoline, the second between isolines 40 and $45 \mathrm{~dB}$ and the third between 35 and $40 \mathrm{~dB}$. Additionally, the Table 4 lists the calculated equivalent noise level $\mathrm{A}-\mathrm{L}_{\mathrm{AeqN}}(\mathrm{dB})$ for daytime and night-time.

\section{Discussion}

Our investigation is in agreement with a range of studies demonstrating the decline in numbers and species in the vicinity of roads carrying heavy traffic (Reijnen and Foppen 1994; Reijnen et al. 1995; Kuitunen et al. 1998, Rheindt 2003; Ingelfinger and Anderson 2004; Palomino and Carrascal 2007; Benitez-López et al. 2010; Summers et al. 2011). An important insight emerging from our study is that the species particularly sensitive to road traffic were those nesting near the ground and with low-frequency calls. Very likely, traffic noise is one of the main factors why birds avoid the sides of busy roads (Reijnen et al. 1996, 1997; Kaseloo 2006; Slabbekoorn and Ripmeester 2007). We found a strict relationship between noise levels and 
Table 2 Vegetation at the point-count locations in relation to distance from the road (CF-points-60 m, F-points—-310 m, C-points—560 m)

\begin{tabular}{|c|c|c|c|c|c|}
\hline Variable & CF-points & F-points & C-points & $H_{2,54}$ & $P$ \\
\hline Tree age (years) & $88(63-93)$ & $70(60-93)$ & $83(52-93)$ & 0.771 & ns \\
\hline Canopy cover $(\%)$ & $60(50-60)$ & $50(40-60)$ & $50(40-50)$ & 4.488 & ns \\
\hline Tree height (m) & $15.3(14.6-18.1)$ & $18.1(15-19.5)$ & $17.4(16-19.4)$ & 2.940 & ns \\
\hline Number of tree species & $3.5(2-5)$ & $4(2-5)$ & $4(3-5)$ & 0.165 & ns \\
\hline Number of deciduous trees & $5(2-7)$ & $5.5(1-12)$ & $3.5(2-7)$ & 0.838 & ns \\
\hline Number of dead trees & 0 & $1(0-2)$ & $1(0-2)$ & 7.864 & $<0.05$ \\
\hline $\mathrm{DBH}(\mathrm{cm})$ & $31(27.3-33.6)$ & $30.3(28.2-35.7)$ & $32.3(29.6-35)$ & 1.337 & ns \\
\hline Number of shrub species & $5(4-7)$ & $5(4-6)$ & $5(4-6)$ & 1.037 & ns \\
\hline Shrub cover $(\%)$ & $40(30-50)$ & $40(30-50)$ & $30(10-30)$ & 7.419 & $<0.05$ \\
\hline Herb cover $(\%)$ & $60(40-80)$ & $80(50-90)$ & $90(60-100)$ & 5.819 & ns \\
\hline Herb height $(\mathrm{cm})$ & $29.5(24.4-33)$ & $26.9(25.2-32)$ & $32.6(22.6-39.2)$ & 2.628 & ns \\
\hline
\end{tabular}

Median values, with 25 and $75 \%$ quartiles in parentheses are shown. Differences between points were tested by Kruskal-Wallis test

distance from the road in our study. Our data are generally consistent with predictions of the traffic noise hypothesis, because the number and species diversity of birds were correlated with the pattern of sound propagation across our study area. The greatest decreases were noted in the row of observation points closest to the road; the species richness and the numbers of birds rose with decreasing noise levels. Nonetheless, this dependence is correlational, and we cannot rule out the influence of other factors that we did not assess in our study and which could have modified our picture of the distribution and numbers of birds, such as elevated mortality following collisions with vehicles (Orłowski 2005, 2008), optical disturbances and the penetration of the forest space by vehicle lights (Pocock and Lawrence 2005), pollutants emitted by vehicles, which could have impoverished food resources by reducing insect numbers (poisoning) (Reijnen et al. 1995; Summers et al. 2011). A further factor distorting our picture could have been the differentiation of habitat parameters in our study area (Reijnen et al. 1995). But, we carried out our study in a carefully selected plot deep in the forest, where the habitat was structurally homogeneous. In this way, we attempted to minimize the possible error due to the modifying influence of a non-homogeneous habitat and marginal effect in the study plot (Š́lek et al. 2010; Halfwerk et al. 2011). Only two of the eleven environmental parameters differentiated the plot—shrub layer density and the number of dead trees. The number of dead trees increased and the shrub layer density decreased with distance from the road. But in all probability, this did not have any great influence on the observed distribution of birds: the study plot was managed in accordance with standard forestry practice, and there was not much dead wood lying around as this was cleared from time to time. The greater density of the shrub layer closer to the road was the result of deliberate plantings by the roadside, including non- native species. What could have further complicated the result of this research is the fact that in the present study, we could not completely control the impact of the marginal effect on a breeding community of birds. We found the small variability in vegetation structure at our study area; however, some other factors related to edge effect, such as competition, predation and microclimate conditions could affect and modify the observed pattern of bird distribution (McCollin 1998). Another limiting factor in this type of study is the fact that the observers themselves sometimes have difficulty in hearing the birds above the traffic noise, so some will undoubtedly have gone unrecorded (Rheindt 2003; Summers et al. 2011). Nevertheless, we were aware of these limitations during out point counts and tried to minimize them. Our task was made a little easier because the traffic along the road was not continuous, and we were able to record the birds' vocal activity in the quieter gaps.

The results of this study have serious implications for the conservation and management of avian populations living in habitats in the vicinity of roads, because it showed that with increasing distance from the road, the number of birds nesting on or close to the ground also rose. To the best of our knowledge, this is the first study to demonstrate this phenomenon. This could have been due to a number of factors. First of all, the consequence of a busy road cutting through a large, dense forest is that people penetrate the areas close to the road: car passengers, foresters, as well as mushroom and berry pickers, who could scare birds away from the zone adjacent to the road. Collisions with vehicles are a second important factor: the most vulnerable birds in this respect are those that fly low (Massemin et al. 1998) and that inhabit the lowest layer of vegetation (Orłowski 2008). The excessive traffic noise could also be significant, as its intensity is the greatest close to the ground. More exposed to masking are birds living and singing at low elevations above the ground (Dooling and Popper 2007). 
Table 3 Forest bird community composition in relation to distance from road (CF-points-60 m, F-points-310 m, C-points-560 m) in eastern Poland

\begin{tabular}{|c|c|c|c|c|c|}
\hline \multirow[t]{2}{*}{ Species } & \multirow[t]{2}{*}{ Guilds } & \multirow[t]{2}{*}{ Total number } & \multicolumn{3}{|c|}{ Number of individuals (\%) } \\
\hline & & & CF-points $(n=18)$ & F-points $(n=18)$ & C-points $(n=18)$ \\
\hline Fringilla coelebs & $\mathrm{Hn}, \mathrm{G}, \mathrm{Hf}$ & 277 & $87(31)$ & $89(32)$ & $101(37)$ \\
\hline Erithacus rubecula & Ln, I, Hf & 109 & $31(28)$ & $35(32)$ & $43(40)$ \\
\hline Parus major & $\mathrm{H}, \mathrm{I}, \mathrm{Hf}$ & 94 & $34(36)$ & $29(31)$ & $31(33)$ \\
\hline Periparus ater & $\mathrm{H}, \mathrm{I}, \mathrm{Hf}$ & 71 & $12(17)$ & $28(39)$ & $31(44)$ \\
\hline Sylvia atricapilla & Ln, I, Mf & 58 & $13(22)$ & $23(40)$ & $22(38)$ \\
\hline Phylloscopus collybita & Ln, I, Mf & 49 & $6(12)$ & $15(31)$ & $28(57)$ \\
\hline Anthus trivialis & Ln, I, Hf & 45 & $6(13)$ & $17(38)$ & $22(49)$ \\
\hline Cuculus canorus & $\mathrm{Ln}, \mathrm{I}, \mathrm{Lf}$ & 38 & $2(5)$ & $15(40)$ & $21(55)$ \\
\hline Turdus merula & $\mathrm{Hn}, \mathrm{I}, \mathrm{Hf}$ & 37 & $12(32)$ & $11(30)$ & $14(38)$ \\
\hline Phylloscopus sibilatrix & Ln, I, Hf & 35 & $8(23)$ & $16(46)$ & $11(31)$ \\
\hline Lophophanes cristatus & $\mathrm{H}, \mathrm{I}, \mathrm{Hf}$ & 30 & $4(13)$ & $14(47)$ & $12(40)$ \\
\hline Turdus philomelos & Hn, I, Mf & 27 & $11(40)$ & $8(30)$ & $8(30)$ \\
\hline Dendrocopus major & $\mathrm{H}, \mathrm{G}, \mathrm{Mf}$ & 21 & $5(24)$ & $9(43)$ & $7(33)$ \\
\hline Garrulus glandarius & $\mathrm{Hn}, \mathrm{G}, \mathrm{Mf}$ & 18 & $4(22)$ & $5(28)$ & $9(50)$ \\
\hline Ficedula hypoleuca & $\mathrm{H}, \mathrm{I}, \mathrm{Hf}$ & 14 & $4(29)$ & $6(42)$ & $4(29)$ \\
\hline Oriolus oriolus & $\mathrm{Hn}, \mathrm{I}, \mathrm{Mf}$ & 9 & $2(22)$ & $5(56)$ & $2(22)$ \\
\hline Turdus viscivorus & $\mathrm{Hn}, \mathrm{G}, \mathrm{Mf}$ & 9 & $2(22)$ & $4(44)$ & $3(33)$ \\
\hline Troglodytes troglodytes & Ln, I, Hf & 7 & 0 & $1(14)$ & $6(86)$ \\
\hline Columba palumbus & $\mathrm{Hn}, \mathrm{G}, \mathrm{Lf}$ & 7 & $1(14)$ & $1(14)$ & $5(72)$ \\
\hline Certhia familiaris & $\mathrm{H}, \mathrm{I}, \mathrm{Hf}$ & 5 & 0 & $3(60)$ & $2(40)$ \\
\hline Sitta europaea & $\mathrm{H}, \mathrm{I}, \mathrm{Hf}$ & 4 & 0 & $1(25)$ & $3(75)$ \\
\hline Sylvia borin & Ln, I, Lf & 4 & 0 & $2(50)$ & $2(50)$ \\
\hline Cyanistes caeruleus & $\mathrm{H}, \mathrm{I}, \mathrm{Hf}$ & 3 & 0 & $2(67)$ & $1(33)$ \\
\hline Emberiza citrinella & Ln, I, Hf & 3 & $1(33)$ & 0 & $2(67)$ \\
\hline Regulus ignicapillus & $\mathrm{Hn}, \mathrm{I}, \mathrm{Hf}$ & 2 & 0 & $2(100)$ & 0 \\
\hline Phylloscopus trochilus & Ln, I, Hf & 2 & $1(50)$ & 0 & $1(50)$ \\
\hline Buteo buteo & $\mathrm{Hn}, \mathrm{R}, \mathrm{Hf}$ & 2 & 0 & $2(100)$ & 0 \\
\hline Corvus corax & $\mathrm{Hn}, \mathrm{R}, \mathrm{Mf}$ & 2 & 0 & 0 & $2(100)$ \\
\hline Regulus regulus & $\mathrm{Hn}, \mathrm{I}, \mathrm{Hf}$ & 2 & 0 & $1(50)$ & $1(50)$ \\
\hline Poecile palustris & $\mathrm{H}, \mathrm{I}, \mathrm{Hf}$ & 2 & 0 & $1(50)$ & $1(50)$ \\
\hline Turdus pilaris & Hn, I, Hf & 1 & $1(100)$ & 0 & 0 \\
\hline Picus canus & $\mathrm{H}, \mathrm{I}, \mathrm{Lf}$ & 1 & 0 & 0 & $1(100)$ \\
\hline Phoenicurus ochruros & $\mathrm{H}, \mathrm{I}, \mathrm{Hf}$ & 1 & 0 & 0 & $1(100)$ \\
\hline Pyrrhula pyrrhula & $\mathrm{Hn}, \mathrm{G}, \mathrm{Mf}$ & 1 & 0 & $1(100)$ & 0 \\
\hline Streptopelia turtur & $\mathrm{Hn}, \mathrm{I}, \mathrm{Lf}$ & 1 & 0 & 0 & $1(100)$ \\
\hline Phoenicurus phoenicurus & $\mathrm{H}, \mathrm{I}, \mathrm{Mf}$ & 1 & 0 & 0 & $1(100)$ \\
\hline Luscinia luscinia & Ln, I, Mf & 1 & 0 & 0 & $1(100)$ \\
\hline Sylvia communis & Ln, I, Hf & 1 & 0 & 0 & $1(100)$ \\
\hline Dryocopus martius & $\mathrm{H}, \mathrm{I}, \mathrm{Mf}$ & 1 & 0 & $1(100)$ & 0 \\
\hline Total & & 995 & 247 & 347 & 401 \\
\hline
\end{tabular}

The explanation of bird classification according to nesting, foraging and bioacoustics guilds: $H$ hole nesters, $H n$ high nesters, $L n$ low nesters, $R$ raptorial, $G$ granivorous-insectivorous, $I$ insectivorous, $H f$ high-frequency singers, $M f$ medium-frequency singers, $L f$ low-frequency singers. The percentages shown in parentheses

Species nesting higher up in the vegetation or in the tree crowns are less exposed to all these factors; hence, they made up a considerable proportion of the birds counted in the point row $60 \mathrm{~m}$ from the road. Despite the lack of statistically significant differences in the structure of the vegetation on the study plot, we can not completely 


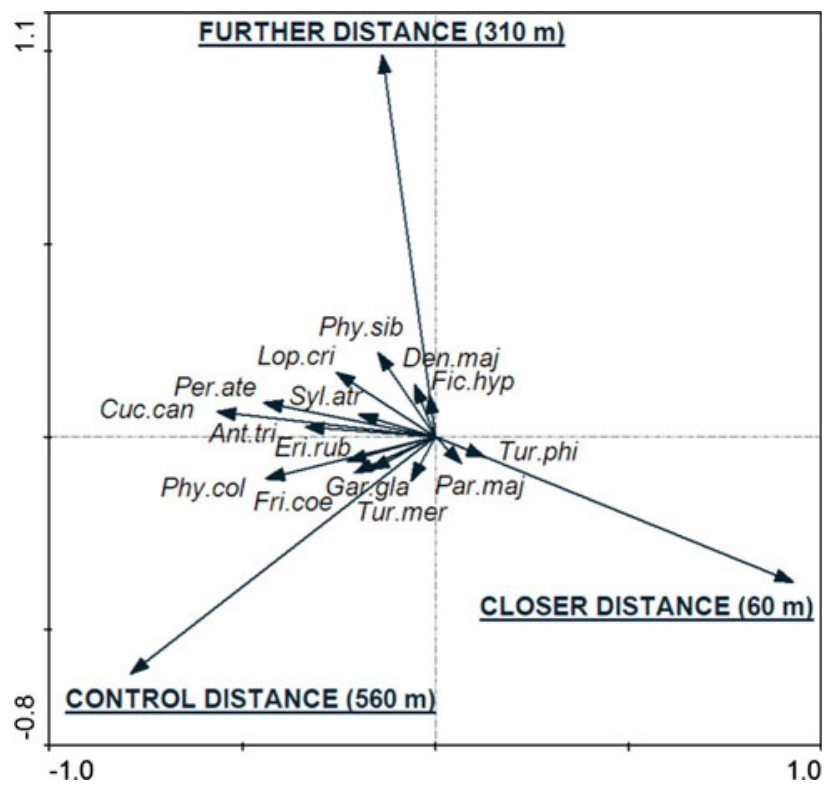

Fig. 3 Ordination diagram of redundancy analysis (RDA) with 15 of the most common bird species recorded in Janów Forest (eastern Poland) explained by the point-count locations in relation to distance from the road. Abbreviations of species names include the first three letters of the genus and species scientific names

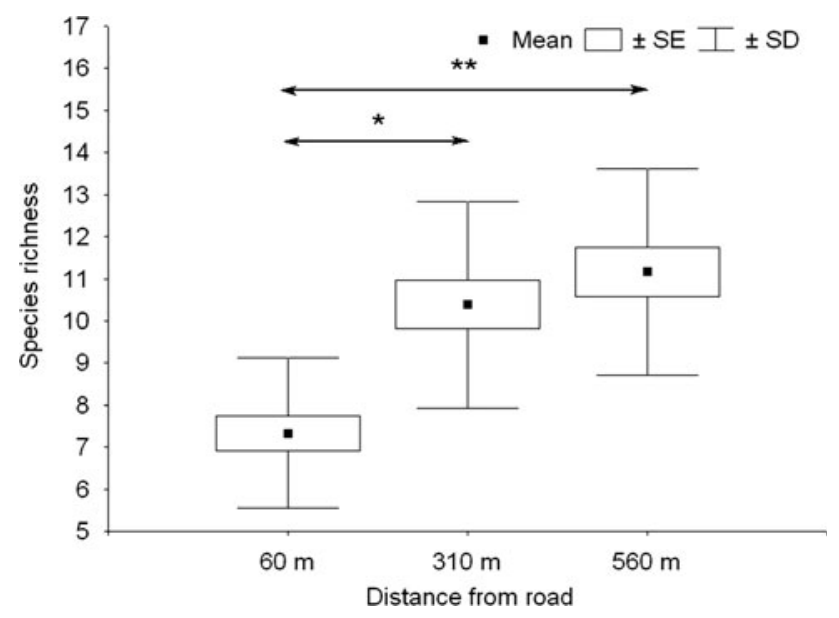

Fig. 4 Relationship between bird species richness at point-count locations and distance from the road. Arrow shows significant differences between points (Tuckey test, $* P<0.001$, ** $P<0.0005)$

exclude the impact of the marginal effect and the structure of the forest ecosystem on the observed pattern of distribution of birds. We found that species vocally communicating using low-frequency sounds avoided roadsides, principally the cuckoo, the wood pigeon Columba palumbus, the garden warbler Sylvia borin, the grey-green woodpecker Picus canus and the turtle dove Streptopelia turtur. These species avoided the immediate vicinities of roads in order to prevent their songs/calls being masked by the noise of traffic. As many authors have emphasized, it is

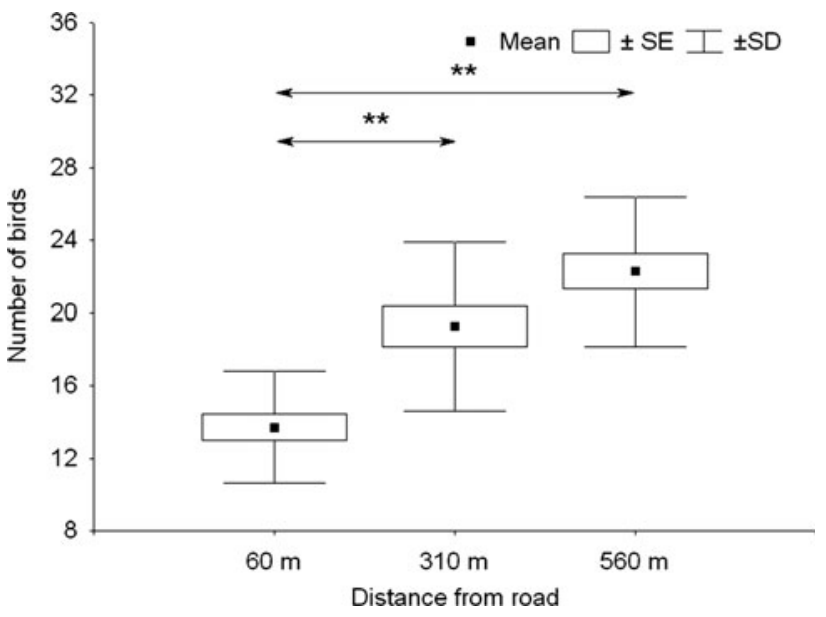

Fig. 5 Relationship between bird abundance at point-count locations and distance from the road. Arrow shows significant differences between points (Tuckey test, $* * P<0.0005$ )

those species communicating vocally with the aid of lowfrequency sounds that are most exposed to masking by noise (Trombulak and Frissell 2000; Rheindt 2003; Brumm 2004; Halfwerk et al. 2011). Analysis of the feeding guilds indicates that with distance from the road, there was a drop in the numbers of seed-eaters and species with mixed diets. This could have been due to the edge effect created by lines of communication (Ferris 1979; Helle 1983; Šálek et al. 2010; Summers et al. 2011). The edges of roads have a richer vegetation structure, a larger proportion of segetal plants and can also offer food from anthropogenic sources (Helle and Muona 1985; Huhta et al. 1999; Kuitunen et al. 2003). But, nesting on woodland margins carries a greater threat from predators, which more often hunt along the edges of a habitat than in its interior (Kuitunen and Helle 1988; Ratti and Reese 1988). The selection of an ecotone as a nesting site is thus encumbered with a greater risk: a site with superior food resources that is subject to greater pressure from predation (Benitez-López et al. 2010). On the other hand, roadsides might be safer places for nesting because the road traffic would discourage predators (Pescador and Peris 2007). Our research has confirmed this, indicating a low degree of penetration of our study plot by predators wanting to plunder egg clutches/broods (Kucharczyk et al. unpublished data).

Our observations showed that the only species displaying a preference for the busy road were the great tit and song thrush. The reasons why song thrush should prefer roadsides remains unknown, but many authors stress the exception flexibility of great tit (Reijnen et al. 1995). This species has demonstrated a range of adaptations for nesting in noise-polluted habitats. The latest studies indicate that great tit raises the frequency of its song in order to avoid the frequencies at which its song would be masked (Salaberria and Gil 2010). Other papers, however, point to the 

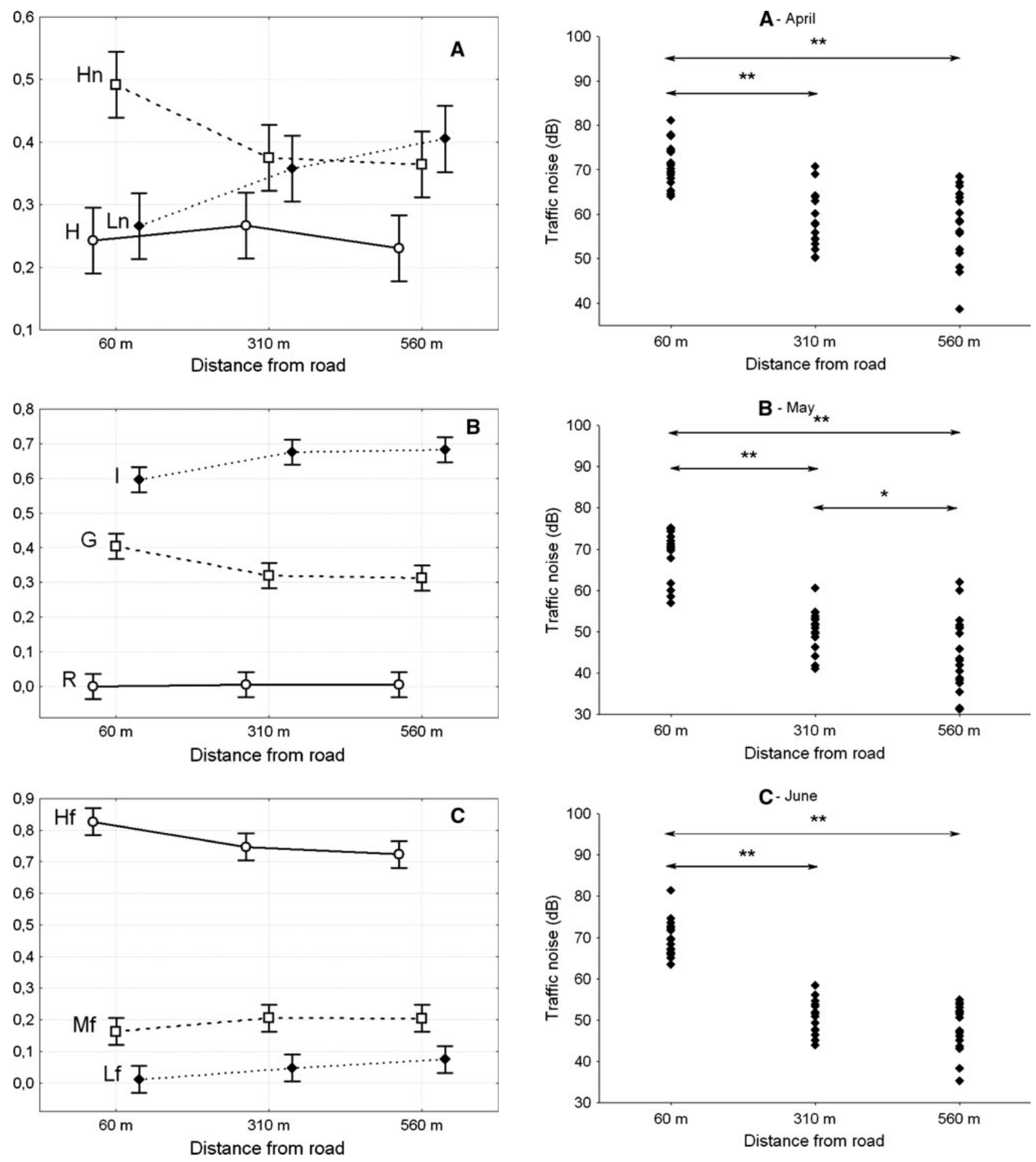

Fig. 6 Nesting (a $H$ hole nesters, $H n$ high nesters, $L n$ low nesters), foraging (b $R$ raptorial, $G$ granivorous-insectivorous, $I$ insectivorous) and bioacoustics (c $H f$ high-frequency singers, $M f$ medium-frequency singers, $L f$ low-frequency singers) guilds in relation to the distance from road. Vertical lines indicate $95 \%$ confidence intervals

fact that the great tit's nesting near busy roads has its costs and reduces its breeding success (Halfwerk et al. 2011). Our observations bear this out: on our study plot, we found

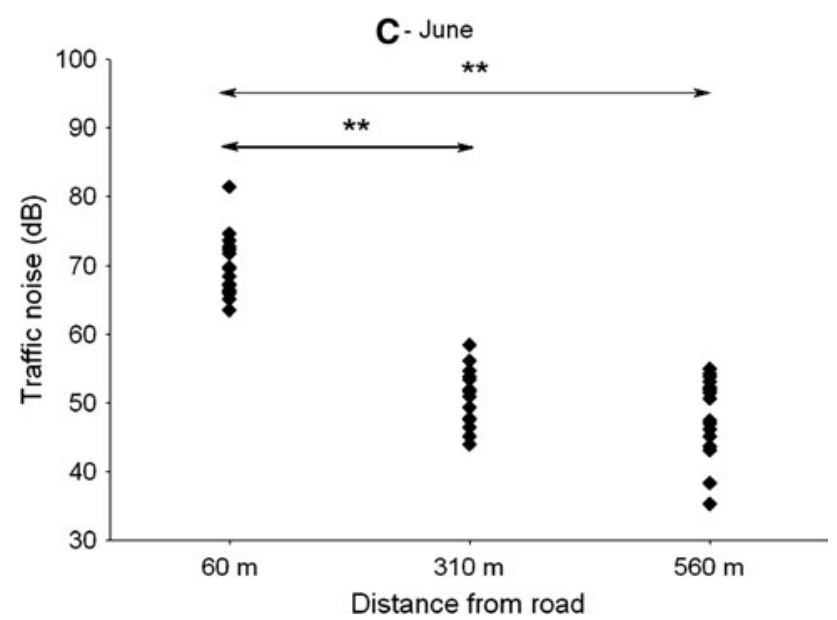

Fig. 7 Relationship between A-weighted traffic noise (dB) at pointcount locations and distance from the road in April (a), May (b) and June (c). Arrow shows significant differences between points (Tuckey test, $* P<0.001, * * P<0.0005)$

an elevated mortality among nestlings in Great Tit nests close to the road, probably because the parent birds had been killed in collisions with vehicles. 
Table 4 Equivalent continuous A-weighted sound pressure level $\mathrm{L}_{\text {Aeq }}[\mathrm{dB}]$ in relation to distance from road (CF-points- $60 \mathrm{~m}$, F-points-310 m, C-points-560 m) in eastern Poland

\begin{tabular}{lllll}
\hline Points & $\begin{array}{l}\text { Period of } \\
\text { day }\end{array}$ & Mean \pm SD & Minimum & Maximum \\
\hline $\begin{array}{c}\text { CF-points } \\
(n=18)\end{array}$ & Day & $60.0 \pm 0.3$ & 59.5 & 60.5 \\
F-points & Night & $56.2 \pm 0.3$ & 55.7 & 56.7 \\
$\quad$ Day & $43.1 \pm 0.3$ & 42.6 & 43.4 \\
C-points & Night & $39.3 \pm 0.3$ & 38.8 & 39.6 \\
$(n=18)$ & Day & $39.1 \pm 0.1$ & 38.9 & 39.2 \\
\hline & Night & $35.3 \pm 0.1$ & 35.1 & 35.4 \\
\hline
\end{tabular}

This study indicates the need to undertake action to minimize the negative effects of roads on birds. In the design of new roads, it is important to have them pass through artificial or natural depressions in the terrain, like cuttings, gorges or valleys. In order to reduce the risk of collision between birds and vehicles, flight to the danger zone can be impeded, or the roads can be designed in such a way as to make them less attractive to the species susceptible to collisions. Well-designed plantings or opaque acoustic screens can minimize the adverse effects of noise on woodland birds.

Acknowledgments We thank two anonymous referees for critically reviewing previous versions of the manuscript. Regional Nature Protection Directive in Lublin and Forest Inspectorates in Janów Lubelski provided the appropriate permits. We would like to thank Janusz Bohatkiewicz and Maciej Hałucha from EKKOM Ltd. for preparing the map of our study area.

Open Access This article is distributed under the terms of the Creative Commons Attribution License which permits any use, distribution, and reproduction in any medium, provided the original author(s) and the source are credited.

\section{References}

Adams LW, Geis D (1981) Effects of highway on wildlife. Report No. FHWA/RD-81/067. Office of Research. Federal Highway Administration. US Department of Administration, Washington

Benitez-López A, Alkemade R, Verweij PA (2010) The impacts of roads and other infrastructure on mammal and bird populations: a meta-analysis. Biol Conserv 143:1307-1316

Bermudez-Cuamatzin E, Rios-Chelen AA, Gil D, Garcia CM (2012) Experimental evidence for real-time song frequency shift in response to urban noise in a passerine bird. Biol Lett 7:36-38

Bibby CJ, Burgess ND, Hill DA (1992) Bird census techniques. Academic Press, London

Brumm H (2004) The impact of environmental noise on song amplitude in a territorial bird. J Anim Ecol 73:434-440

Brumm H, Slabbekoorn H (2005) Acoustic communication in noise. Adv Study Behav 35:151-209

Brumm E, Slater PJB (2006) Ambient noise, motor fatigue, and serial redundancy in chaffinch song. Behav Ecol Sociobiol 60:475-481
Clark WD, Karr JR (1979) Effects of highway on red-winged blackbird and horned lark population. Wilson Bull 91:143-145

Cramp S, Perrins CM (eds) (1977-1994) The birds of the Western Palearctic, vols 1-9. Oxford University Press, Oxford

Diaz M, Parra A, Gallardo C (2011) Serins respond to anthropogenic noise by increasing vocal activity. Behav Ecol 22:332-336

Dooling RJ, Popper AN (2007) The effects of highway noise on birds. The California Dept. of Transportation. Division of Environmental Analysis, Sacramento

Fahrig L, Rytwinski T (2009) Effects of roads on animal abundance: an empirical review and synthesis. Ecol Soc 14:21

Fahrig L, Pedla JH, Pope SE, Taylor PD, Wegner JF (1995) Effect of road traffic on amphibian density. Biol Conserv 73:177-182

Ferris CR (1979) Effects of Interstate 95 on breeding birds in northern Maine. J Wildlife Manag 43:421-427

Forman RT, Sperling D (2003) Road ecology: science and solutions. Island Press, Washington

Fuller RA, Warren PH, Gaston KJ (2007) Daytime noise predicts nocturnal singing in urban robins. Biol Lett 3:368-370

Habib L, Bayne EM, Boutin S (2007) Chronic industrial noise affects pairing success and age structure of ovenbirds Seiurus aurocapilla. J Appl Ecol 44:176-184

Halfwerk W, Holleman LJM, Lessells CM, Slabbekoorn H (2011) Negative impact of traffic noise on avian reproductive success. J Appl Ecol 48:210-219

Helle P (1983) Bird communities in open ground-climax forest edges in north eastern Finland. Oulanka Rep 3:39-46

Helle P, Muona J (1985) Invertebrate numbers in edges between clear-fellings and mature forests in northern Finland. Silva Fenn 19:281-294

Huhta E, Jokimäki J, Rahko P (1999) Breeding success of pied flycatchers in artificial forest edges: the effect of a suboptimally shaped foraging area. Auk 116:528-535

Ingelfinger F, Anderson S (2004) Passerine response to roads associated with natural gas extraction in a sagebrush steppe habitat. West North Am Nat 64:385-395

Kaseloo PA (2006) Synthesis of noise effects on wildlife populations. In: Irwin CL, Garrett P, McDermott KP (eds) Proceedings of the 2005 International Conference on Ecology and Transportation. Center for Transportation and the Environment, North Carolina State University, Raleigh, pp 33-35

Kuitunen M, Helle P (1988) Relationship of the common treecreeper Certhia familiaris to edge and forest fragmentation. Orn Fenn 65:150-155

Kuitunen M, Rossi E, Stenroos A (1998) Do highways influence density of land birds? Environ Manage 22:297-302

Kuitunen MT, Viljanen J, Rossi E, Stenroos A (2003) Impact of busy roads on breeding success in Pied Flycatchers Ficedula hypoleuca. Environ Manage 31:79-85

Lackey MA, Morrison ML, Loman ZG, Fisher N, Farrell SL, Collie BA, Wilkins RN (2011) Effects of road construction noise on the endangered golden-cheeked warbler. Wild Soc Bull 35:15-19

Leonard ML, Horn AG (2008) Does ambient noise affect growth and begging call structure in nestling birds? Behav Ecol 19:502-507

Massemin S, Maho Y, Handrich Y (1998) Seasonal pattern in age, sex and body condition of Barn Owls Tyto alba killed on motorways. Ibis 140:70-75

McCollin D (1998) Forest edges and habitat selection in birds: a functional approach. Ecography 21:247-260

McGregor RL, Bender DJ, Fahrig L (2008) Do small mammals avoid roads because of the traffic? J Appl Ecol 45:117-123

Orłowski G (2005) Factors affecting road mortality of the Barn Swallow Hirundo rustica in farmland. Acta Ornithol 40:117-125

Orłowski G (2008) Roadside hedgerows and trees as factors increasing road mortality of birds: implications for management 
of roadside vegetation in rural landscapes. Land Urban Plan 86:153-161

Ortega YK, Capen DE (1999) Effects of forest roads on habitat quality for ovenbirds in a forested landscape. Auk 116:937-946

Palomino D, Carrascal LM (2007) Threshold distances to nearby cities and roads influence the bird community of a mosaic landscape. Biol Conserv 140:100-109

Pescador M, Peris S (2007) Influence of roads on bird nest predation: an experimental study in the Iberian Peninsula. Land Urban Plan 82:66-71

Pocock Z, Lawrence RE (2005) How far into a forest does the effect of a road extend? Defining road edge effect in eucalypt forests of SouthEastern Australia. In: Irwin CL, Garrett P, McDermott KP (eds) Proceedings of the 2005 International Conference on Ecology and Transportation. Center for Transportation and Environment, North Carolina State University, Raleigh, pp 397-405

Ratti JT, Reese KP (1988) Preliminary test of the ecological trap hypothesis. J Wild Manage 52:484-491

Reijnen R, Foppen R (1994) The effects of car traffic on breeding bird population in woodland. I. Evidence of reduced habitat quality for willow warblers Phylloscopus trochilus breeding close to a highway. J Appl Ecol 31:85-94

Reijnen R, Foppen R, Ter Braak C, Thiessen J (1995) The effects of car traffic on breeding bird populations in woodland. III. Reduction of density in relation to the proximity of main roads. J Appl Ecol 32:187-202

Reijnen R, Foppen R, Meeuwsen H (1996) The effects of traffic on the density of breeding birds in Dutch agricultural grasslands. Biol Conserv 75:255-260

Reijnen R, Foppen R, Veenbaas G (1997) Disturbance by traffic of breeding birds: evaluation of the effect and considerations in planning and managing road corridors. Biodiv Conserv 6:567-581
Rheindt FE (2003) The impact of roads on birds: does song frequency play a role in determining susceptibility to noise pollution? J Ornith 144:295-306

Salaberria C, Gil D (2010) Increase in song frequency in response to urban noise in the Great Tit Parus major as show by data from the Madrid (Spain) city noise map. Ardeola 57:3-11

Šálek M, Svobodová J, Zasadil P (2010) Edge effect of low-traffic forest roads on bird communities in secondary production forests in central Europe. Landsc Ecol 25:1113-1124

Slabbekoorn H, Ripmeester EAP (2007) Birdsong and anthropogenic noise: implications and applications for conservation. Mol Ecol 17:72-83

Spellerberg IF, Morrison T (1998) The ecological effects of new roads: a literature review. New Zealand Department of Conservation, Wellington

Statsoft Statsoft Inc (2001) Statistica for Windows (data analysis system). Version 6

Summers PD, Cunnington GM, Fahrig L (2011) Are the negative effects of roads on breeding birds caused by traffic noise? J Appl Ecol 48:1527-1534

Ter Braak CJF, Smilauer P (1998) CANOCO reference manual and user's guide to Canoco for Windows: software for canonical community ordination (version 4). Microcomputer Power, New York

Trombulak SC, Frissell CA (2000) Review of ecological effects of roads on terrestrial and aquatic communities. Conserv Biol 14:18-30

Wiley RH, Richards DG (1982) Adaptation for acoustic communication in birds: sound transmission and signal detection. In: Kroodsma DE, Miller EH (eds) Acoustic communication in birds, vol 1. Academic Press, New York, pp 131-181

Wood WE, Yezerinac SM (2006) Song Sparrow (Melospiza melodia) song varies with urban noise. Auk 123:650-659 